\title{
Unaided dispersal risk of Magallana gigas into and around the UK: combining particle tracking modelling and environmental suitability scoring
}

\author{
Louisa E. Wood (D) Tiago A. M. Silva (iD) Richard Heal • Adam Kennerley (iD • \\ Paul Stebbing $\cdot$ Liam Fernand $(\mathbb{D} \cdot$ Hannah J. Tidbury $(\mathbb{B}$
}

Received: 19 September 2020/ Accepted: 19 January 2021 / Published online: 3 February 2021

(C) Crown 2021

\begin{abstract}
Marine non-indigenous species are a significant threat to marine ecosystems with prevention of introduction and early detection considered to be the only effective management strategy. Knowledge of the unaided pathway has received relatively little attention, despite being integral to the implementation of robust monitoring and surveillance. Here, particle tracking modelling is combined with spatial analysis of environmental suitability, to highlight UK coastal areas at risk of introduction and spread of Magallana gigas by the unaided pathway. 'Introduction into UK' scenarios were based on spawning from the continental coast, Republic of Ireland, Channel Islands and Isle of Man and 'spread within UK' scenarios were based on spawning from known UK wild populations and
\end{abstract}

Supplementary Information The online version contains supplementary material available at https://doi.org/10.1007/ s10530-021-02467-x.

L. E. Wood $(\varangle) \cdot$ R. Heal · A. Kennerley · H. J. Tidbury

Centre for Environment Fisheries and Aquaculture

Science, Weymouth, Dorset, UK

e-mail: Louisa.wood@cefas.co.uk

T. A. M. Silva $\cdot$ L. Fernand

Centre for Environment, Fisheries and Aquaculture

Science, Lowestoft, Suffolk, UK

P. Stebbing

APEM Ltd, International House, Southampton International, Business Park, Southampton,

Hampshire, UK aquaculture sites. Artificial structures were included as spawning sites in an introduction scenario. The UK coast was scored, based on parameters influencing larval settlement, to reflect environmental suitability. Risk maps were produced to highlight areas of the UK coast at elevated risk of introduction and spread of $M$. gigas by the unaided pathway. This study highlights that introduction of M. gigas into UK waters via the unaided pathway is possible, with offshore structures increasing the potential geographical extent of introduction. Further, there is potential for substantial secondary spread from aquaculture sites and wild populations in the UK. The results of the study are considered in the context of national M. gigas management, whilst the approach is contextualised more broadly as a tool to further understanding of a little-known, yet significant pathway.

Keywords Surveillance $\cdot$ Risk analysis $\cdot$ Pacific oyster · Crassostrea gigas · GETM · GITM

\section{Introduction}

Effective prevention of non-indigenous species (NIS) introduction and spread requires a comprehensive understanding of introduction pathways, in addition to a robust framework that facilitates prioritisation of pathways for management. Pathway assessments are 
crucial to understand the relative risk of different pathways, identify locations at high risk of introduction, inform risk based biosecurity and surveillance, and aid assessment of costs in order to inform management and policy decisions (e.g. Hulme et al. 2008; CBD 2014; Essl et al. 2015; Cassey et al. 2018). Pathway analysis has tended to focus a priori on key 'deliberate' and 'accidental' human-mediated pathways and associated vectors, given that mitigation to reduce associated risk is likely possible through targeted biosecurity efforts. Several studies have quantified pathway activity associated with a particular location (Tidbury et al. 2016), environment (Williams et al. 2013) or species group (Zenni 2014), with the aim of informing management. The unaided pathway (i.e. natural dispersal of a species after its initial introduction into another territory (Hulme et al. 2008)), has received comparatively little attention, likely due to impediments in understanding and managing this pathway (Hulme 2015). Further, difficulties in attributing introductions of NIS to the unaided pathway with certainty may result in poor documentation of the risk posed by this pathway and a likely underestimation of its importance in global assessments (Hulme et al. 2008; Essl et al. 2015). However, an understanding of the unaided pathway is vital to guide decisions on risk-based biosecurity and surveillance and in the prioritisation of species for management, with re-introduction risk and feasibility of pathway management being an important consideration in species management feasibility (Booy et al. 2017).

Species-pathway interactions are often complex, with several discrete introduction routes contributing to propagule pressure. The Pacific oyster, Magallana gigas (previously Crassostrea gigas), is one example of a widespread marine NIS for which management decisions are particularly challenging. Magallana gigas is native to warm temperate regions, specifically the Northwest Pacific and Sea of Japan (Herbert et al. 2016). However, the species has been introduced into more than 66 countries outside of its native range, mainly for aquaculture, with self-sustaining populations reported in at least 17 of these countries (Ruesink et al. 2005; Smaal et al. 2006; Cardoso et al. 2007; Wrange et al. 2010). In addition to aquaculture, its spread is associated with shipping (ballast water, hull fouling), and live trade (live seafood, bait) pathways (Herbert et al. 2012; d'Auriac et al. 2017).
Magallana gigas has a dispersive pelagic phase, typically lasting 2-4 weeks (Helm 2004) that comprises three temperature dependent pelagic larval stages of different durations (trochophore, veliger, pediveliger). The species is known to disperse via ocean currents, resulting in its spread over large areas (approx. $50 \mathrm{~km}$ ) (Brandt et al. 2008). Hard substrate, such as rocks, man-made structures, small stones, or living or dead shells of other animals, is required for settlement (Kochmann et al. 2013). Magallana gigas has been shown to colonise wind farms in the North Sea (De Mesel et al. 2015) and such artificial structures have been suggested to act as potential 'stepping stones' in long distance dispersal of NIS (Coolen et al. 2020), possibly contributing to changes in distribution (Adams et al. 2014). Wild establishment in non-native ecosystems has likely been favoured by a lack of natural predators, beneficial species traits such as rapid growth, and rising air and sea temperatures due to global warming (see Troost 2010 for a review). Impacts in its non-native range may be in the form of ecological impacts, such as the displacement of native species and habitats through the formation of reef systems (Herbert et al. 2012), or socio-economic impacts, such as injuries caused by shells on leisure beaches and blockage of navigational channels for recreational vessels (Herbert et al. 2016).

In the UK $M$. gigas is an important aquaculture species, with an annual production of 1,200 tonnes and a value of $£ 4,911,600$ (Ellis et al. 2015). Despite assumptions that $M$. gigas would not establish in the wild in UK waters, self-sustaining populations are widely reported in the warmer waters of the South of England. However, only a few isolated populations are reported in the more northern and cooler waters (Natural England 2009; Herbert et al. 2012; Smith et al. 2015). Its commercial value yet 'moderate' risk as an invasive species (GB NNSS 2010; Copp et al. 2016), render policy decisions concerning $M$. gigas challenging and controversial (Herbert et al. 2016). Through altering species communities, wild settlement of $M$. gigas may change the condition of European marine sites that have been designated as protected under the Conservation of Habitats and Species Regulations 2010. Authorisation of new $M$. gigas aquaculture sites is therefore considered in the context of wild populations and their potential impacts. However, prohibition of aquaculture is only likely to be effective in reducing the risk of $M$. gigas 
spread if effective management of all pathways is in place (Booy et al. 2017). A comprehensive evidence base from which to formulate management and policy decisions is therefore crucial. However, despite its potential role in the introduction and spread of $M$. gigas into and around the UK and implications for species management, understanding of the risk associated with the unaided pathway remains limited for this species.

The aim of this study was to apply particle tracking modelling, integrating hydrodynamics and biological behaviour of pelagic larvae, to gain insight into the potential dispersal of $M$. gigas into and within UK waters, via the unaided pathway, in order to inform its management. The risk of introduction into the UK was simulated based on spawning of larvae from populations outside the UK (continental coast (France, Belgium, Netherlands, Germany), Channel Islands, Isle of Man (IoM) and Republic of Ireland (RoI)) (Fig. 1), both with and without the inclusion of spawning from windfarms. Secondary spread was simulated based on spawning from locations where wild populations are recorded or aquaculture sites are registered in the UK. A worst-case scenario of unaided dispersal was modelled, to align with the precautionary principle outlined in the Convention on Biological Diversity (CBD). Results indicate that within one spawning season (i.e. 1 year), introduction of M. gigas into the UK from outside is possible, with offshore structures increasing the potential geographical extent of introduction on the south-east coast of England. Further, results indicate potential for secondary spread around the UK from known aquaculture sites and wild populations. These results are discussed in the context of M. gigas management in the UK and highlight the need to consider the unaided pathway for effective species control. Further, the importance of transboundary management of highly dispersive NIS is highlighted.

\section{Methods}

Magallana gigas distribution data

Colonisation of the continental coastline (France, Belgium, Netherlands, Germany) by M. gigas was assumed, guided by the precautionary principle of NIS management, known distribution records (GBIF 2019) and discussion with experts (Arjan Gittenberger, pers. comm. 12th June 2019; Cécile Masse, pers. comm. 29th June 2019) (see Fig. 1).

Occurrence records of wild populations in the UK, RoI, Channel Islands and IoM were obtained from Marine Recorder v5 2020.02.06 (JNCC 2019). Records were assessed and verified based on discussion with experts and unverified records were discarded (see Fig. 1).

Data detailing the location of $M$. gigas aquaculture sites in England and Wales were obtained from the Fish Health Inspectorate (FHI) of the Centre for Environment, Fisheries and Aquaculture Science (Cefas), data from Scotland were obtained from Scottish Government (aquaculture.scotland.gov.uk), and data from Northern Ireland and RoI were collated from Department of Agriculture, Environment and Rural Affairs (DAERA). Data from the Channel Islands were obtained from the government of Jersey (https://www.gov.je). Aquaculture sites active within the last three years were used.

Wind farm locations (polygon boundaries) were taken from the OSPAR offshore renewables database from 2018 (https://odims.ospar.org/layers/geonode: ospar_offshore_renewables_2018_01_002/metadata_ detail). Windfarms determined to be located within maximum dispersal distance from introduction origins (i.e. continental coast, Channel Islands, RoI, and IoM coastlines) based on initial particle tracking simulations, were considered colonised to simulate a worstcase scenario.

\section{Hydrodynamic model}

The hydrodynamic model Generalised Estuarine Transport Model, GETM v2.4, (www.getm.eu; Burchard et al. 2002) for the North Western European Shelf domain was run, at a three nautical mile resolution (Fig. 1) to provide the ocean current velocities and turbulence for the advection and diffusion of larvae. The model was run in $3 \mathrm{D}$ with 25 sigma layers distributed non-homogenously and was forced by tidal constituents from TOPEX-POSEIDON (Le Provost et al. 1998) and full meteorological forcing from ECMWF ERA Interim reanalysis (Berrisford et al. 2011; Dee et al. 2011; www.ecmwf.int/en/research/ climate-reanalysis/era-interim). 3D current velocities and vertical diffusivity variables were saved hourly to resolve the effect of tides. For more details and 


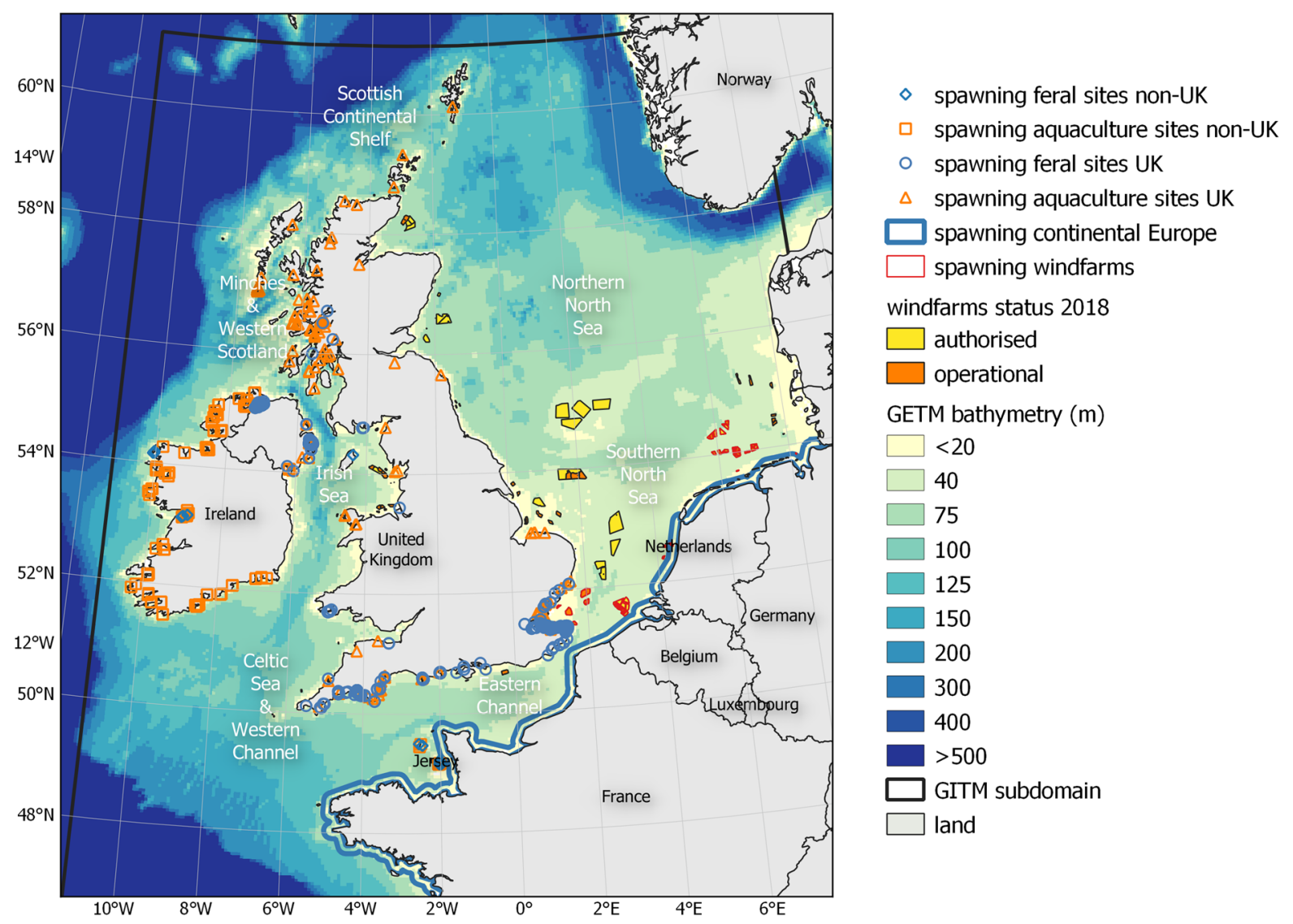

Fig. 1 Bathymetric map of the model domain with release sites depicted for particle tracking scenarios. Spawning was assumed to occur from release sites for the purposes of modelling and is not based on records of actual spawning in these locations

validation refer to Van der Molen et al. (2016). Each scenario was run for 2013, 2014, and 2015 to include interannual variability.

\section{Particle tracking model}

The particle tracking model General Individual Transport Model, GITM 2.0, combines physical advection and diffusion with biological development and behaviour to allow particles to progress through defined development stages. It uses ocean currents from the hydrodynamic model for the advection and diffusion of eggs and larvae. This was done with the diffusive random walk from Visser (1997) to correct for spatially varying diffusivity. Horizontal diffusion is constant while the turbulence from GETM is used to infer vertical diffusion of particles. Vertical migration behaviours (neutrally buoyant, floating, sinking, diel migration, tidally cued migration) were defined for each development stage (see Spawning and Larval Development). In order to reduce the number of particles required for a simulation, each particle represented a super-individual with a set amount of health, which is reduced over time according to a mortality rate or function. This is more computationally efficient than having particles subject to mortality at random according to a probability. Particle trajectory outputs from GITM were output into a netCDF file every 30 minutes. Both GETM and GITM were run on the High-Performance Computing cluster at the University of East Anglia (UEA).

Model Setup and scenarios

The hydrodynamic model GETM and the particle tracking model GITM were combined to allow dispersal of $M$. gigas larvae to be simulated. The domain of GETM was the north-eastern Atlantic 
Ocean, encompassing areas of the Celtic Sea, English Channel, North Sea and southern Irish Sea. The GITM domain was limited to the continental shelf to reduce computational demands (see Fig. 1).

Four scenarios were simulated: (A) Spawning (i.e. particle release) from the continental coast (France, Belgium, Netherlands, Germany), RoI, Channel Islands and IoM (hereafter referred to as spawning from populations outside the UK); (B) As in A but including spawning from windfarms (C) Spawning from known aquaculture sites in the UK; (D) Spawning from wild populations in the UK (Fig. 1).

Under Scenario A, the continental coast was assumed to be colonised continuously; $M$. gigas is widespread across the continental coast (GBIF 2019) and suitable biotic and abiotic conditions are present for species establishment (Wrange et al. 2010). Spawning locations were defined as a $15 \mathrm{~km}$ buffer along the coastline from 47 to $54^{\circ} \mathrm{N}$. Note that, particles were not released from locations east of the mouth of the River Elbe, Germany, as preliminary ocean current analysis indicated negligible risk of dispersal to the UK from these locations. Spawning from wild and aquaculture sites in the RoI, IoM and Channel Islands were also included under Scenario A (see Fig. 1).

Under scenario $\mathrm{B}$, the potential contribution of offshore windfarms as stepping stones for the introduction of $M$. gigas was explored by adding spawning from windfarms (within maximum dispersal distance from introduction origins outlined in scenario A) to scenario A. Particles were released from 26 discrete areas in the North Sea, occupied by windfarms, with colonisation of M. gigas assumed at each of these sites.

For scenarios $\mathrm{C}$ and $\mathrm{D}$, spawning from all known UK aquaculture sites and wild populations respectively was simulated.

Spawning sites across RoI, Channel Islands, IoM and UK related to model grid cells $(5.5 \times 5.5 \mathrm{~km})$ within which the species is documented as present. For the continental coastal and windfarm polygons (Fig. 1) spawning sites related to $3 \times 3$ model grid cells (around $16.5 \mathrm{~km}$ spacing) given that the forcing fields vary smoothly between cells. An initial test showed that using a $5.5 \mathrm{~km}$ model grid for spawning sites combined with a $5 \mathrm{~km}$ wide coastal polygon along the continental coastline resulted in a patchier spawning distribution (when compared to a $16.5 \mathrm{~km}$ interval). Further analysis was undertaken for each scenario to determine how many particle releases were necessary to meet the maximum dispersal. The number of particles released in each of the spawning seasons i.e. per year simulated, is listed in Table 1. The total number of particles released per spawning season i.e. year, under each scenario was the result of the number of release locations and the number of releases per day.

\section{Spawning and larval development}

Spawning in $M$. gigas occurs in response to environmental triggers once gonad maturation is reached, with a threshold temperature of $16{ }^{\circ} \mathrm{C}$ required (Rico-Villa et al. 2009; Dutertre et al. 2010; Kochmann 2012) to trigger spawning, in addition to other environmental cues (Bernard et al. 2016). Mann (1979) modelled this maturation period for larvae from Kent, UK, as 600-degree days above $10.55{ }^{\circ} \mathrm{C}$. The onset of spawning in the present study was informed by the median maturation date ( 7 th July) for the years 2013-2015 based on Mann (1979), and published literature that reports that spawning in M. gigas has been reported to occur as early as June-July in northern Europe (Lango-Reynoso et al. 2006). Since $M$. gigas is a broadcast spawner, spawning dates were randomly sampled from a normal distribution with mean 15th July and a standard deviation of four days. This meant that $95 \%$ of the releases happened between the 7 th and 22nd July. The relationship between $M$. gigas larval survival and temperature or salinity is not well known, thus the effect of these parameters on survival was not modelled. Changing the simulated spawning date, therefore, only affects the initial tidal and wind driven currents.

Larvae that reached land by diffusion were reflected back into the sea, so that no early settling/wastage occurred, and larvae remained in circulation, maximising the statistical power of the results (Van der Molen et al. 2015). A larval mortality value of 0.044 day $^{-1}$ was taken from Galtsoff (1964, in Rumrill 1990). A constant larval mortality was incorporated into the model as a fractional reduction in health at every biological time step. Particle health was used to weight each particle when calculating settling probabilities i.e. the number of particles surviving to settlement stage and occurring in a $5 \mathrm{~km}$ grid cell. 
Table 1 The number of M. gigas records, spawning locations and number of particles released

\begin{tabular}{lllll}
\hline & Scenario & $\begin{array}{l}\text { Total number of data } \\
\text { records for M. gigas }\end{array}$ & $\begin{array}{l}\text { Number of modelled spawning } \\
\text { locations }(5.5 \times 5.5 \mathrm{~km})\end{array}$ & $\begin{array}{l}\text { Number of released particles per } \\
\text { spawning season i.e. year }\end{array}$ \\
\hline $\begin{array}{l}\text { Continental } \\
\text { coastline }\end{array}$ & A, B & - & 303 & 15,000 \\
$\begin{array}{c}\text { RoI, Channel } \\
\text { Islands, IoM }\end{array}$ & A, B & 214 & 45 & 7000 \\
$\begin{array}{l}\text { Windfarms } \\
\text { Aquaculture }\end{array}$ & B & - & 69 & 6100 \\
$\quad$ UK & 132 & 78 & 10,800 \\
Wild UK & D & 483 & 63 & 7800 \\
\hline
\end{tabular}

The number of records is not stated for the continental coastline or windfarms as colonisation of the entire coastline, and all polygons with windfarms present, was assumed. Spawning locations (i.e. particle release sites) across RoI, Channel Islands, IoM and UK relate to model grid cells $(5.5 \times 5.5 \mathrm{~km})$ within which the species is recorded. Spawning locations across the continental coastline and spawning sites across areas occupied by windfarms reflect points at $15 \mathrm{~km}$ intervals

Based on previous work (Coon et al. 1990; Collet et al. 1999; Troost 2010; Robins et al. 2017) biological development was split into three stages: Stage (1) trochophores (1.5 days); Stage (2) veligers (19.5 days) and Stage (3) pediveliger: competent larvae, capable of settling (7 days); modelled as in Robins et al. (2017). At $5 \mathrm{~km}$ resolution GETM does not allow representation of most estuaries and the intertidal area. It is considered that by the time the larvae reach the coastal grid cells of the model, they are at veliger stage (Stage 2), when larvae are capable of active swimming (Troost et al. 2008). Thus, the trochophore stage, is considered implicit in the model, and particles are released as veligers. It is assumed that particles released from estuaries and intertidal flats did not settle within these areas and continued to disperse as veligers. 19.5 days later these enter the settling stage and seven days after that are removed from the simulation (see Table 2).

Bivalve larvae are known to exhibit vertical migration in response to tidal movement, which is thought to enhance dispersal (Knights et al. 2006, Troost et al. 2008). For Stage 2 of the model this was represented by an upward migration during the rising tide and downward during the falling tide. The vertical velocities were set to $0.003 \mathrm{~ms}^{-1}$ according to the swimming velocities seen in the laboratory by Newell et al. (2005) for Crassostrea virginica pediveligers. This is on the upper limit $\left(0.001-0.003 \mathrm{~ms}^{-1}\right)$ of estimates for Mytilus spp. (James et al. 2019). During Stage 3, the larvae were competent to settle and swim towards the bed (Arakawa 1990). A speed of
$0.01 \mathrm{~ms}^{-1}$ was chosen to overcome vertical transport and diffusion and allow the particles to remain close to the seabed (see Table 2).

Larval dispersal and model outputs

Particle trajectories were plotted and used to calculate the number of particles in settling stage (Stage 3) for each $5 \mathrm{~km}$ grid cell. Each particle was weighted by its health value, which takes mortality into account. The number of particles in settling stage therefore decreased with time (as probability of death increases with time). The number of particles in settling stage for each $5 \mathrm{~km}$ grid cell was normalised across the model domain.

Environmental suitability scoring

Environmental data covering UK waters, defined by the UK EEZ, were obtained for the four significant parameters influencing settlement, survival, growth and development of M. gigas larvae (henceforth termed 'settlement'), namely ocean temperature (SST) (Met Office Hadley centre EN4.2.0 ocean series), water salinity (Met Office Hadley centre EN4.2.0 ocean series), seabed substrate type (UKSeaMap 2018, JNCC), and ocean depth (EMODNet Bathymetry data portal (https://emodnet.eu). Although local hydrodynamic conditions, e.g. wave action, impact the settlement of oyster larvae (Fuchs et al. 2015), they were not considered in this study due 
Table 2 Summary of development stage parameterisation for M. gigas

\begin{tabular}{lll}
\hline & Pelagic larvae (veliger) & Settling larvae (pediveliger) \\
\hline Duration & 19.5 days & $\leq 7$ days (Coon et al. 1990) \\
Mortality & 0.044 day $^{-1}$ (Galtsoff 1964) & \\
Vertical migration & Tidal (North et al. 2008) & Attempt settling (Robins et al. 2017) \\
Vertical velocity & $0.003(-0.003) \mathrm{ms}^{-1}$ (Newell et al. 2005) & Downward 0.01 (-0.01) ms ${ }^{-1}$ (present study) \\
Horizontal swimming & None & None \\
\hline
\end{tabular}

to a lack of high resolution, coastal hydrodynamic data for the entire study area. Environmental parameters and suitability ranges for $M$. gigas are summarised in Table 3. Environmental data processing was performed in R v.3.5.3 ( $\mathrm{R}$ Core Team 2019) using the package raster (Hijmans 2019). UK waters were split into 10,892 grid cells $\left(0.11^{\circ} \times 0.11^{\circ}\right)$ and scored to reflect their suitability for $M$. gigas larval settlement. Grids with optimal, suboptimal and unsuitable $M$. gigas conditions were scored two, one and zero respectively for each environmental parameter. An overall score was generated by calculating the mean, with any cell recording a zero score for any of the four parameters being assigned a value of 0 . Environmental suitability scores were therefore either zero, or in a range between one; where all the environmental parameters were suboptimal and two, where all the environmental parameters were optimal.

Comparison of the environmental suitability scoring and the recorded M. gigas populations (wild and aquaculture) was used to validate the scoring methodology (see Fig. 3).

Table 3 Magallana gigas environmental suitability

\begin{tabular}{|c|c|c|c|}
\hline $\begin{array}{l}\text { Environmental } \\
\text { parameters }\end{array}$ & Range/classification & $\begin{array}{l}\text { Suitability } \\
\text { classification }\end{array}$ & Reference \\
\hline \multirow[t]{3}{*}{ Temperature $\left({ }^{\circ} \mathrm{C}\right)$} & $0-3$ & Unsuitable & $\begin{array}{l}\text { Mann et al. (1991), Ruiz et al. (1992), Kochmann (2012), Robins et al. } \\
\text { (2017) }\end{array}$ \\
\hline & $3-16$ & Suboptimal & $\begin{array}{l}\text { Mann et al. (1991), Ruiz et al. (1992), Kochmann (2012), Robins et al. } \\
\text { (2017) }\end{array}$ \\
\hline & $16-35$ & Optimal & $\begin{array}{l}\text { Mann et al. (1991), Ruiz et al. (1992), Castaños et al. (2009), } \\
\text { Kochmann (2012), Robins et al. (2017) }\end{array}$ \\
\hline \multirow[t]{2}{*}{ Salinity (ppt) } & $0-11$ & Unsuitable & Mann et al. (1991), Ruiz et al. (1992), Kochmann (2012) \\
\hline & $11-34$ & Optimal & Mann et al. (1991), Ruiz et al. (1992), Kochmann (2012) \\
\hline \multirow[t]{2}{*}{ Depth (m) } & $>40$ & Unsuitable & FAO (2016) \\
\hline & $0-40$ & Optimal & FAO (2016) \\
\hline \multirow[t]{8}{*}{ Substrate } & Rock and hard & Optimal & Seafish (2019), FAO (2019) \\
\hline & Coarse & Optimal & \\
\hline & Mixed sediment & Optimal & \\
\hline & Sandy Mud & Suboptimal & \\
\hline & Sand & Suboptimal & \\
\hline & Muddy sand & Suboptimal & \\
\hline & Fine mud & Suboptimal & \\
\hline & Seabed & Suboptimal & \\
\hline
\end{tabular}

For each environmental parameter the unsuitable, suboptimal (if appropriate) and optimal range (with respect to temperature, salinity and depth) and classification (with respect to substrate) is documented 
Risk maps

Particle tracking outputs and environmental suitability scores were combined to create risk maps to indicate M. gigas introduction and spread risk in UK coastal waters. The risk map grid was based on ICES statistical rectangles split into sixteenths. Risk map grid cells were attributed a 'dispersal' score for each spawning scenario by summing maximum (across years 2013, 2014 and 2015) particle tracking scores (particles in settling stage (Stage 3)) falling within the cell. Similarly, risk map grid cells were attributed a 'suitability' score by summing environmental suitability scores (environmental suitability for larval settlement) falling within the cell. A suitability map was created. Cells with scores $<1,1-2,2-3,3-4$ and $>5$ were categorised as 'very low', 'low', 'moderate', 'high' and 'very high' suitability, respectively. For each risk map grid cell, the larval dispersal score was multiplied by the suitability score to provide an estimated risk score. Risk scores were scaled between 0 and 100 . Risk maps were produced by colour grading each cell to reflect the relative risk of introduction/ spread of $M$. gigas into the cell. Cells with scores $<1$, $1-5,5-25,25-50$ and $>50$ were categorised as 'very low', 'low', 'moderate', 'high' and 'very high' risk, respectively. The number of cells currently occupied by $M$. gigas, and for which dispersal to, and settlement in, is possible under each scenario was calculated. Figure 2 provides an illustration of the methodology implemented in this study.

\section{Results}

Environmental suitability

Coastal regions of England and Wales, below a latitude of $54^{\circ} \mathrm{N}$ (Fig. 3), had the greatest environmental (temperature, salinity, substrate and depth) suitability for larval settlement. Off-shore areas in the North Sea, the Strait of Dover and sections of the eastern Irish Sea also had high environmental suitability. Suitability was only moderate east of the IoM due to a seabed substrate of sandy mud (ICES sub-area VIIa; Table S1). Environmental suitability was generally lower in northern England and Scotland with small regions of higher suitability around the Western Isles, Moray Firth and around the Firth of Forth (ICES sub-area IVa, IVb and VIa). In Northern Ireland, environmental suitability was highest on the southeastern coast (ICES sub-area VIIa). Lower environmental suitability in the northern parts of the UK was driven largely by suboptimal temperatures for $M$. gigas settlement. Spatial heterogeneity in bathymetry and substrate also influenced environmental suitability, with salinity having comparatively little effect at the spatial scale considered. As such, although temperature is a major driver of environmental suitability, for an accurate assessment all environmental factors must be considered in combination.

Risk of introduction and secondary spread

Scenario A: spawning from populations outside the $U K$

Simulations and environmental suitability analyses suggest that dispersal and subsequent settling of $M$. gigas in the UK following spawning from the continental coast was possible (see Figs. 4, 5a). More specifically, $M$. gigas larvae may have dispersed into and subsequently settled within regions north of the Strait of Dover, and south of Lowestoft (ICES subarea IVc), and isolated locations on the south coast of England (ICES sub-areas VIId) (see Figs. 4a, 5b). Locations at moderate to high relative risk of introduction were located on the south-east coast of England (see Fig. 5a). Particle trajectories suggested that potential source locations on the continent are predominantly on the north-east coast of France (see Fig. 4a).

Simulations indicated that introduction into UK waters was also possible following spawning in the IoM and RoI, with high to moderate risk of introduction in coastal waters south of the Channel of the River Esk (ICES sub-area VIIa) and south of Barra and Tiree (ICES sub-area VIa) (Figs. 4a, 5a). Dispersal into UK coastal waters following spawning from the Channel Islands was not observed (Fig. 4a).

Simulations indicated that introduction into $79 \mathrm{UK}$ coastal grid cells was possible; $75(95 \%)$ of which were not occupied by aquaculture sites and $72(91 \%)$ of which were not occupied by wild populations of $M$. gigas (see Table 4; Fig. 5a). 


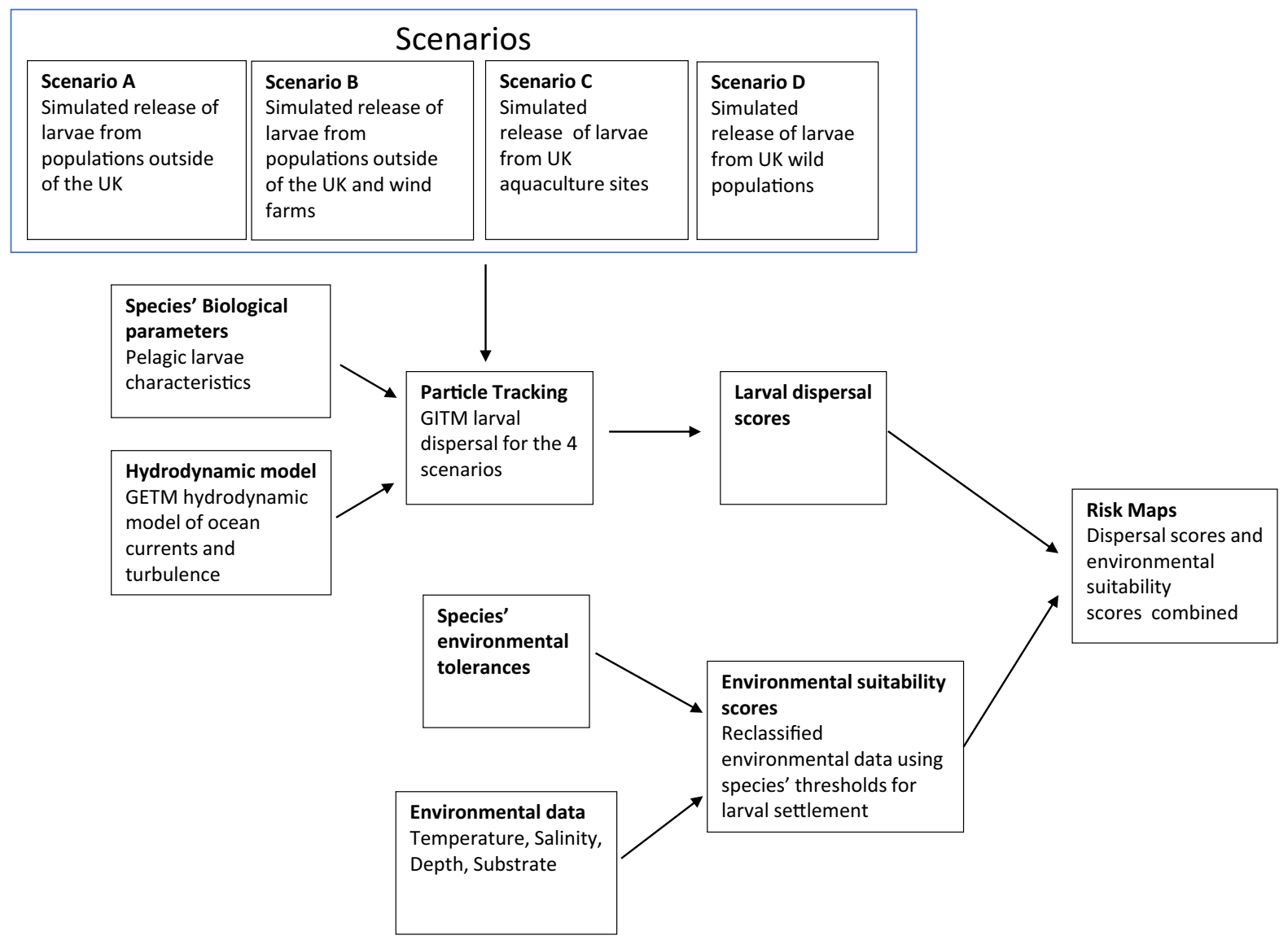

Fig. 2 Summary of methods used in this study

Scenario B: spawning from wind farms in North Sea and populations outside of the $U K$

Inclusion of windfarms as spawning sites increased the geographical extent of the south-east coast of England into which dispersal was possible, specifically the Essex and Suffolk estuaries rather than just Kent (see Fig. 4b). Potential introduction into an additional 12 risk map grid cells was seen when spawning from windfarms was included (see Table 4; Fig. 5b).

\section{Scenario C: spawning from aquaculture sites in the $U K$}

Particle trajectories indicated that dispersal of larvae into the Sea of Hebrides, and around the Orkneys and Shetlands, Anglesey and the Severn Estuary was likely (Fig. 4c). However, given that environmental conditions are unfavorable due to suboptimal sea temperatures in the region (Fig. 3), successful settlement, and risk of secondary spread into these locations is low to very low (Fig. 5c).

UK coastal areas at risk of secondary spread from active UK aquaculture sites were located on the south coast of England, around the Thames estuary, the Bristol Channel, the River Mersey, the east coast of Northern Ireland and the west coast of Scotland (ICES subregion IVc, VIIe, VIIf, VIIa and VIa) (See Fig. 5c). Locations at high risk of secondary spread occurred off the Dorset coast.

Potential secondary spread from UK aquaculture sites into 271 risk map grid cells was predicted, of which $232(86 \%)$ were outside locations where aquaculture sites are currently present and 241 ( $89 \%$ ) of which were outside locations where wild populations of M. gigas are present (Fig. 5c; Table 4). 


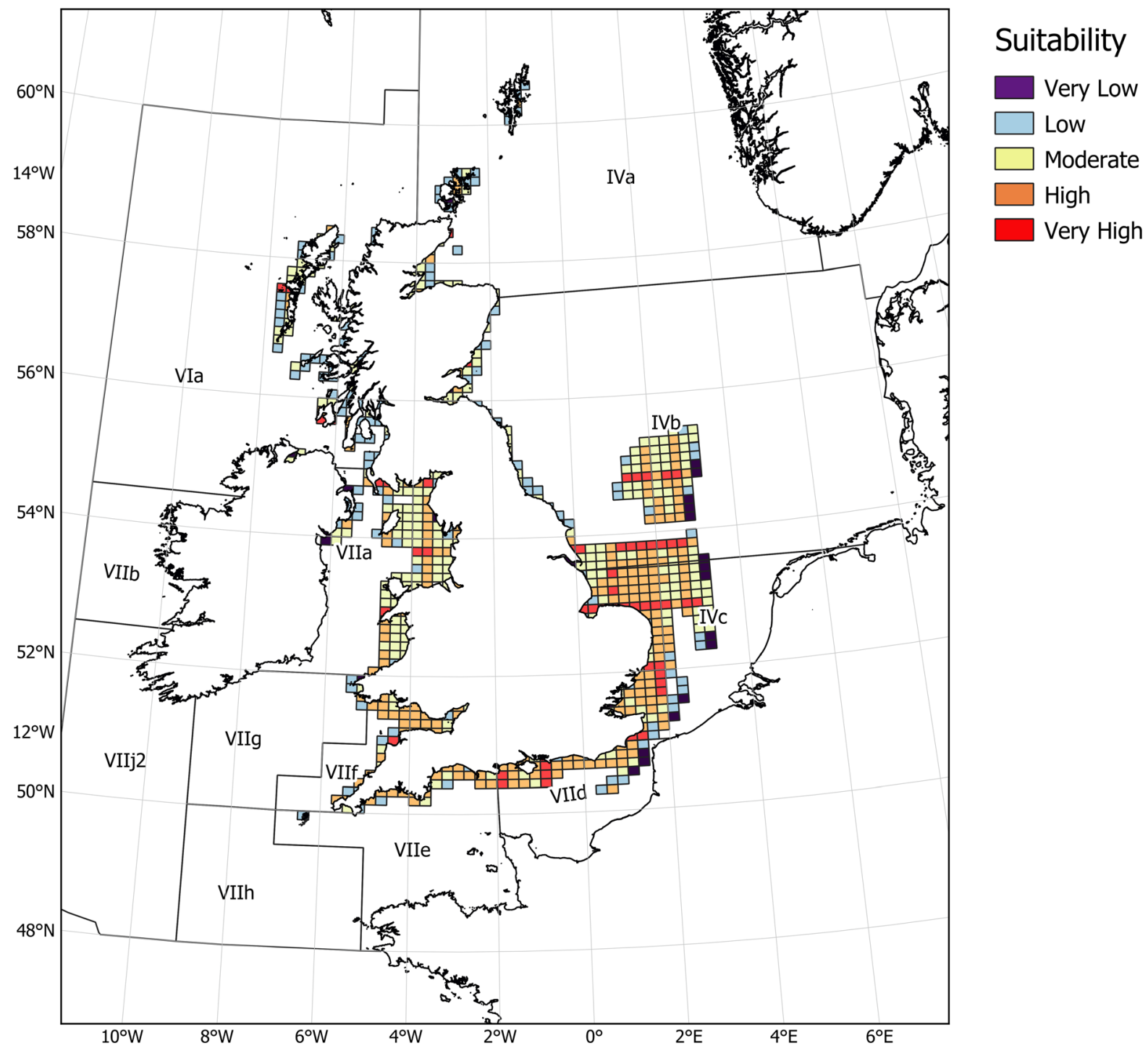

Fig. 3 Magallana gigas environmental suitability based on ocean temperature, water salinity, seabed substrate type, and ocean depth. Environmental conditions were scored as either optimal or suboptimal for larval settlement and the suitability score was taken as the mean of these scores. Any area with an

Scenario D: spawning from wild populations in the $U K$

Risk of secondary spread from known established wild $M$. gigas populations in the UK was greatest along the south coast of England (ICES subregions IVc, VIId and VIIe) and around the Bristol Channel (VIIf) (see Fig. 5d). Locations at very high to high risk of secondary spread occurred around the Thames estuary, and off parts of the Dorset and West Sussex coast (see Fig. 5d). Locations at environmental factor unsuitable for larval settlement was scored as unsuitable. Cells with scores $<1,1-2,2-3,3-4$ and $>5$ were categorised as 'very low', 'low', 'moderate', 'high' and 'very high' suitability, respectively

low or very low risk of secondary spread occurred on the west coast of Scotland (ICES subregion VIa) and south of the channel of the River Esk (ICES subregion VIIa).

A total of 194 grid cells around the UK were at risk of potential introduction and settlement of larvae from spawning on wild sites in the UK. $166(86 \%)$ risk cells occurred outside locations where aquaculture sites are currently present in the UK and 161 (83\%) risk cells occurred in locations where wild populations of $M$. gigas are not currently present. 


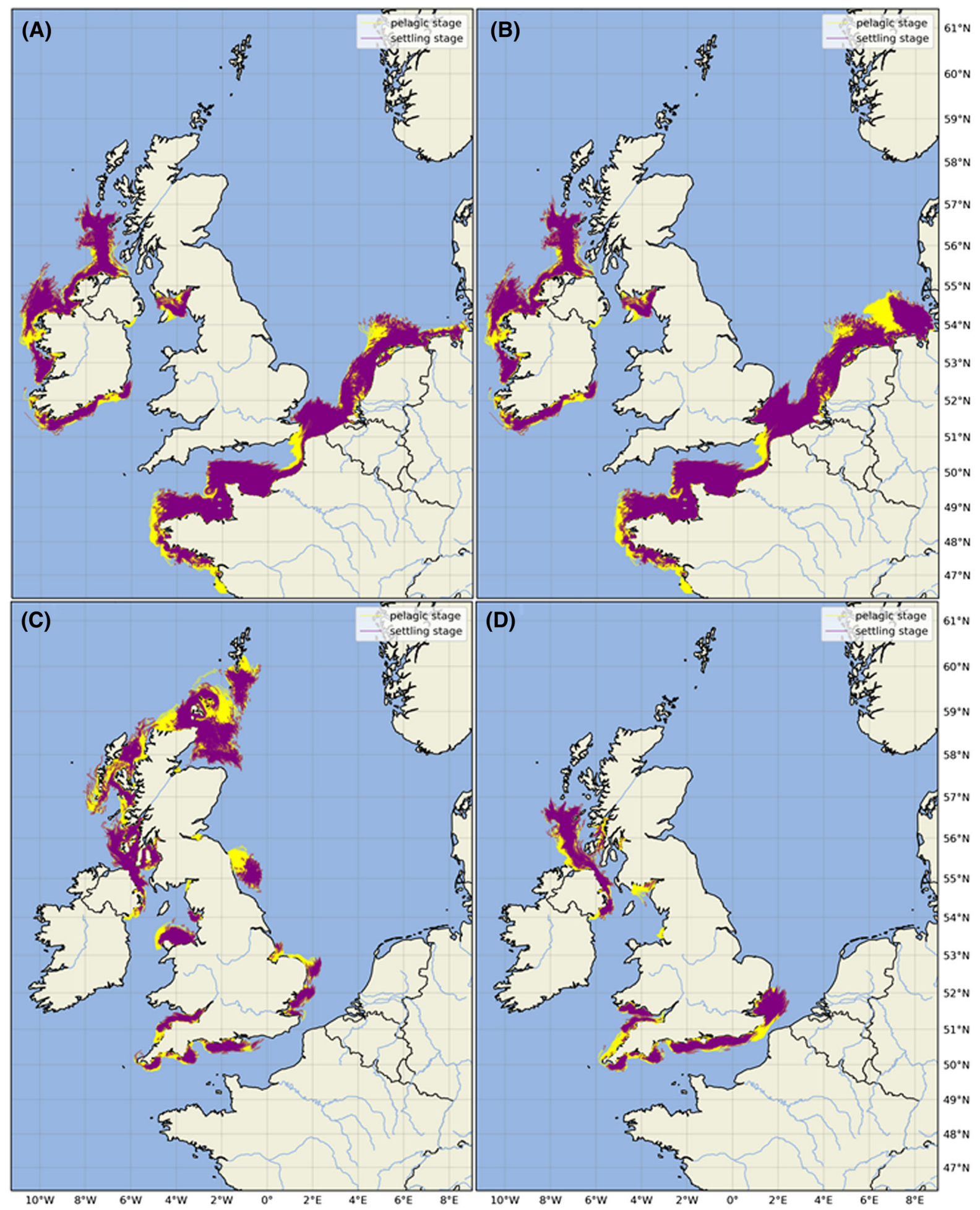

Fig. 4 Particle tracking model. Larval trajectories during the pelagic and settling stage for a introduction from spawning of populations outside the UK $\mathbf{b}$ introduction from windfarm

spawning and spawning of populations outside the UK c secondary spread from aquaculture spawning d secondary spread from wild spawning 
(A)

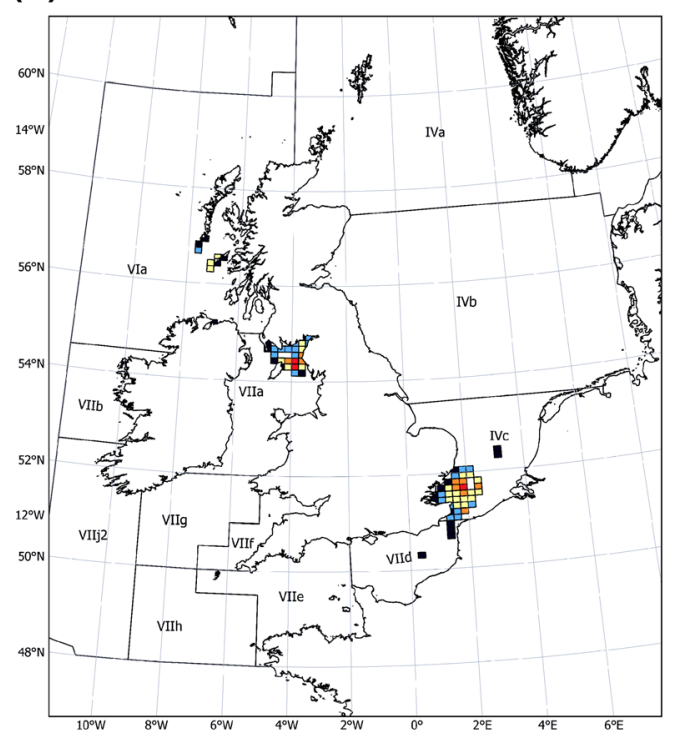

(C)

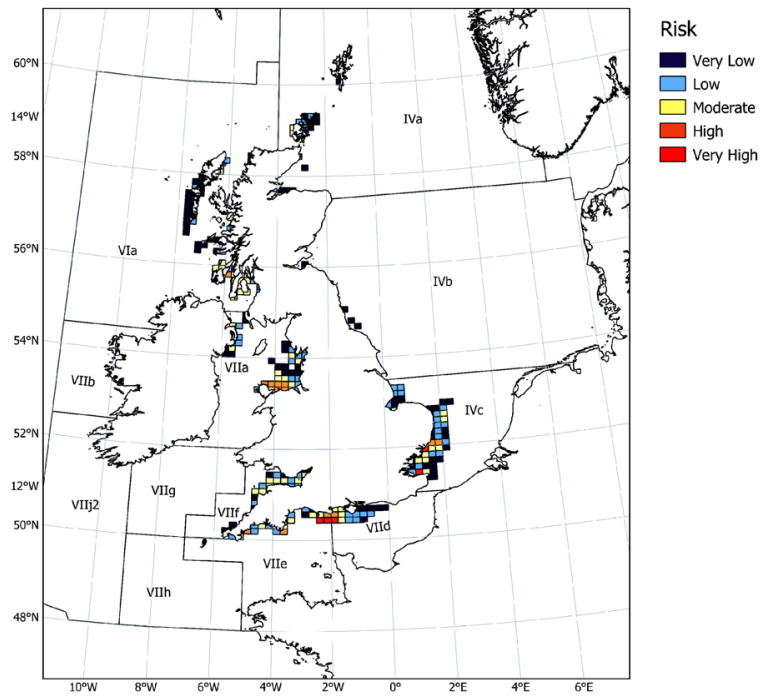

Fig. 5 Risk map illustrating the relative risk of a introduction from spawning of populations outside the UK $\mathbf{b}$ introduction from windfarm spawning and spawning of populations outside the UK c secondary spread from aquaculture spawning

\section{Discussion}

A comprehensive evidence base is vital to inform NIS management. Despite this, understanding of the importance of the unaided pathway in marine NIS introduction and spread remains limited for many species. Understanding all pathways and their
(B)

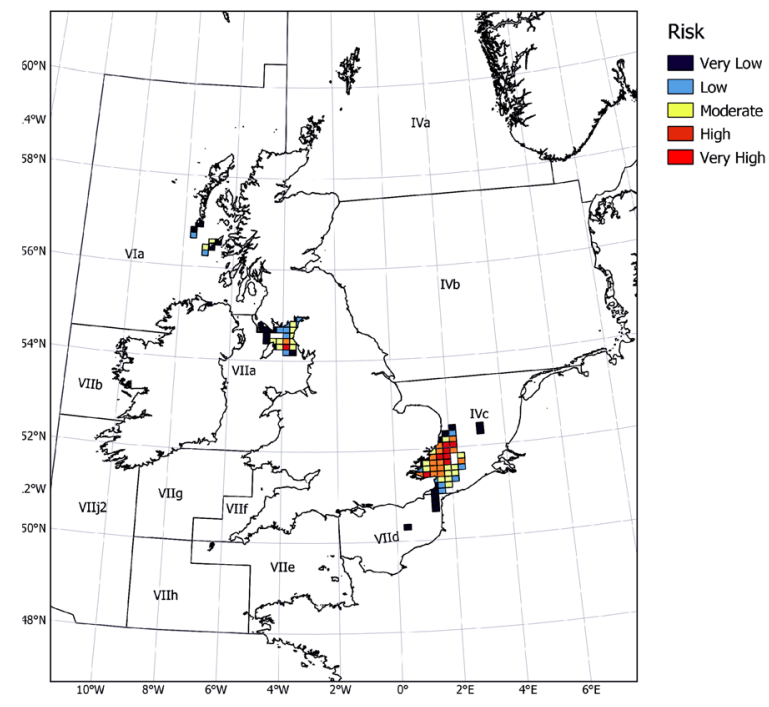

(D)

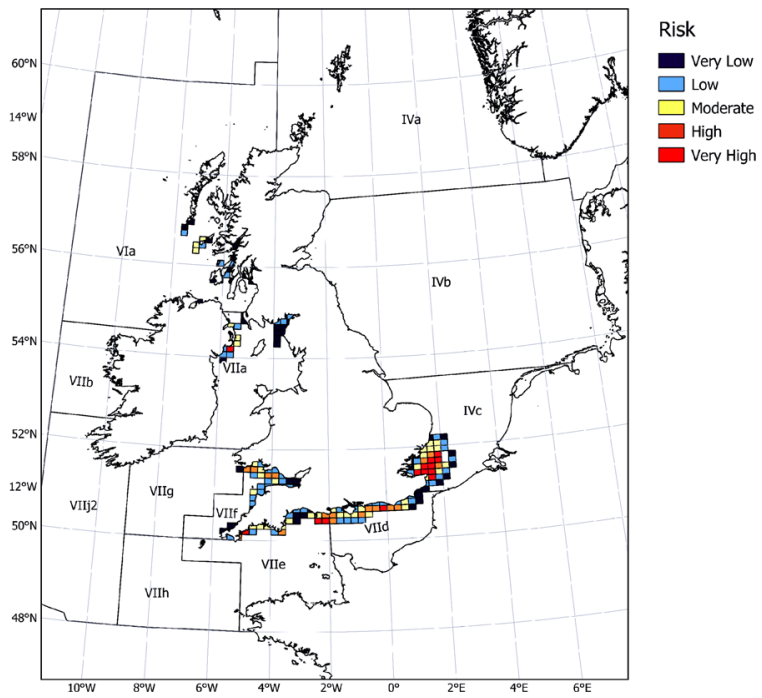

d secondary spread from wild spawning. Cells with scores $<$ $1,1-5,5-25,25-50$ and $>50$ were categorised as 'very low', 'low', 'moderate', 'high' and 'very high' risk, respectively

associated risk, in combination with assessment of the effectiveness of potential management actions, such as biosecurity measures, is required to determine the likely feasibility of NIS management. This study applies a particle tracking modelling approach, in combination with an environmental suitability assessment, to shed light on the potential for M. gigas to be 
Table 4 The number of cells within which aquaculture sites and reported wild UK and RoI populations of M. gigas are located, in addition to the number of cells at risk of introduction under each scenario

\begin{tabular}{lllll}
\hline Scenario & $\begin{array}{l}\text { \# cells } \\
\text { occupied or } \\
\text { 'at risk' }\end{array}$ & $\begin{array}{l}\text { \# cells outside } \\
\text { those occupied by } \\
\text { Aq sites }\end{array}$ & $\begin{array}{l}\text { \# cells outside } \\
\text { those occupied by } \\
\text { wild sites }\end{array}$ & $\begin{array}{l}\text { \# cells outside those } \\
\text { occupied by Aq or } \\
\text { wild sites }\end{array}$ \\
\hline Current aquaculture (Aq) sites & 74 & NA & 54 & NA \\
Current wild sites & 57 & 37 & NA & NA \\
Current aquaculture AND wild sites & 19 & NA & NA & NA \\
Current aquaculture OR wild sites & 110 & NA & NA & NA \\
A. 'Introduction into UK' (not inc windfarm): & 79 & 75 & 72 & 69 \\
$\quad \begin{array}{l}\text { France, Belgium, Netherlands, RoI, Channel } \\
\text { Islands, IoM }\end{array}$ & & & 79 & 74 \\
B. Continent (inc windfarm spawning): France, & 91 & 83 & & 216 \\
$\quad$ Belgium, Netherlands, RoI, Channel Islands, & & & 241 & 146 \\
$\quad$ IoM & 271 & 232 & 317 & 290 \\
C. Aquaculture spawning (UK) & 194 & 166 & 312 & \\
D. Wild spawning (UK) & 353 & & & \\
All spawning scenarios & & & \\
\hline
\end{tabular}

introduced into UK coastal waters following natural dispersal from populations outside the UK (continental coast (France, Belgium, Netherlands, Germany), Republic of Ireland, Channel Islands and Isle of Man), and spread within UK coastal waters, following dispersal from known aquaculture sites and wild populations in the UK. The approach aimed to assess the overall risk of the unaided pathway for M. gigas at a national level, using a precautionary approach, and can be used, in combination with other sources of evidence, to inform national-level policy and management decisions for the species. However, further local-scale modelling will be required to inform site specific management of M. gigas, for example, with respect to understanding the likely contribution of aquaculture activity, relative to other pathways, to wild $M$. gigas population dynamics. The methodology and approach implemented in this study can be applied to other species with pelagic life stages, for different geographical areas and at different spatial resolutions in order to assess the risk of introduction and spread via the unaided pathway.

\section{Unaided introduction into UK waters}

With respect to informing national $M$. gigas management, a few key insights can be gained from this study. Firstly, in a single spawning season (one year), there is potential for both introduction of $M$. gigas into UK coastal waters, and substantial secondary spread from where the species is currently known to occur within the UK. Secondly, offshore structures aid the dispersal of $M$. gigas and may increase the potential geographical area at risk of introduction. Management of the species, both in terms of restrictions on aquaculture sites and management of wild populations, should be considered in light of introduction risk via the unaided pathway from outside the UK, where $M$. gigas populations are not subject to UK jurisdiction and management. The outputs of the precautionary approach taken in this study indicate that, restricting further aquaculture and undertaking management of wild $M$. gigas populations on the south coast of England is unlikely to reduce its long-term distribution dramatically, since introduction events from populations on the continental coast, or from colonised artificial structures in the North Sea, may still occur. Simulations indicated that locations at highest risk of introduction and potential settlement were located on the south-east coast of England, with larval trajectories indicating that $M$. gigas introduction is most likely to occur from where populations have been reported on the north-east coast of France, south of Dunkirk (Dauvin et al. 2019). Herbert et al. (2012) consider cross-channel dispersal between Dover and Calais to occur only under exceptional hydrographic 
conditions, attributing wild settlement in the southeast of the UK to the spread from aquaculture facilities in the region and/or from fouled boats and larvae within ballast water discharges. However, the results of the present study indicate that unaided introduction from populations off the north- east French coastline may be more common than previously considered. Spawning of $M$. gigas occurs in the warmer, summer months. During these months, thermal stratification occurs in the western channel and inhibits lateral exchange between the western and eastern channel. However, the central, eastern channel, Straits of Dover and south North Sea are all vertically mixed with exchange between them occurring freely. Salinity is lower and more variable where the Rhine discharges into the North Sea and this acts as a barrier to hydrological mixing. However, in the summer months this salinity barrier is reduced aiding dispersal across the straits of Dover (Pingree 1980; Otto et al. 1990).

Previous suggestions that genetically distinct wild populations on the south-west coast of the UK originated from natural dispersal from North Brittany (Lallias et al. 2015) seem unlikely based on the particle tracking simulations presented here, which indicate local larval retention on the north-west coast of France. This study presents outputs from models parameterised for three years. It may be possible that extreme conditions (e.g. relating to wind), not captured within these three years, could result in wider dispersal of M. gigas larvae. Further, the occurrence of artificial structures in the English Channel, such as Rampion Wind Farm, not accounted for in the present study, may aid dispersal from France.

This study also highlights that introduction into UK coastal waters south of the Channel of the River Esk and south of Barra and Tiree is possible from the IoM and RoI. Northwards spread of larvae from the south coast of Ireland to Northern Ireland was predicted in the present study, likely due to the prevailing currents in the area (Hill et al. 2008). This emphasises that dispersal is not bounded by political boundaries and highlights the need for communication and coordinated transboundary management of NIS (Hulme 2015). Under modelled conditions, populations of $M$. gigas around the Channel Islands did not disperse to and settle in the UK.

Hard substrate provided by artificial structures offers habitat for fouling species, in often otherwise unsuitable environments (Coolen et al. 2020).
Although representing only a small proportion of hard substrate within the marine and coastal environment, artificial structures often occur in locations where natural hard substrate is absent, providing vital 'stepping-stones' for fouling species and aiding larval dispersal and more broadly marine connectivity (Tidbury et al. 2020). Artificial hard substate is becoming increasingly common in the marine environment. The offshore wind industry alone is rapidly expanding with as many as 2923 turbines already present in UK waters, and more in planning (The Crown Estate 2018). As such, future risk from the unaided pathway may increase, further emphasising the need for its consideration in management and policy decisions.

Unaided spread within UK waters

Results indicate low potential for M. gigas to spread northwards from the south-west and south-east coast of England via natural dispersal. This is perhaps intuitive given the general residual flow within the English Channel, mainly orientated to the east in the eastern channel and along the south coasts of England and to the west along the south-western coasts of England (Salomon and Breton 1993; Hill et al. 2008) i.e. remaining within the Celtic Sea rather than entering the Irish Sea. Particle tracking simulations indicated that larval transport from $M$. gigas populations located in the eastern English Channel was primarily to the north-east. From the coast of Devon and Cornwall, larval transport follows the coastal current around the coast (Hill et al. 2008) Similar patterns of larval dispersal were observed for Pecten maximus stocks (Nicolle et al. 2017). The spread northward in Scotland in the present study is entirely consistent with the general northwards current associated with the Scottish coastal current and flow regime around the UK in summer (Hill et al. 2008). However, risk in the region is low due to low environmental suitability for larval settlement attributed to suboptimal sea temperatures. The low number of established $M$. gigas wild populations off the Scottish coastline supports predictions of low environmental suitability.

The results from this study indicate potential for $M$. gigas to spread substantially within one spawning season. Although temperature is considered the main constraining factor for spread in the UK, our results suggest that it is the interplay between multiple 
environmental suitability parameters and larval dispersal potential that drives distribution changes for this species. For example, reflecting all scenarios, $M$. gigas could occupy three times more UK coastal cells than currently occupied by known aquaculture sites and wild populations. However, given that a precautionary approach was adopted herein, it is more likely that gradual spread over multiple years will occur. Elsewhere in Europe, M. gigas rapid spread has been attributed to a combination of several factors, including increasing suitability of water temperature for natural recruitment and dispersal (Diederich 2005). Evidence to support this comes from several locations, including Denmark and Norway (Wrange et al. 2010), France (Dutertre et al. 2010), Germany (Diederich 2005) and the Netherlands (Wehrmann et al. 2000). Other factors thought to contribute to rapid expansion include gregarious settlement of larvae, and attraction to conspecifics, which results in the rapid formation of reef systems (Diederich 2005; Troost 2010).

\section{Management considerations}

Outputs from this study suggest that large areas of the UK coast are not currently at risk of introduction or spread of $M$. gigas via the unaided pathway (e.g. risk score of zero). This broadly corresponds with the current UK distribution of M. gigas, with the species being notably absent from most of Scotland, Northern Ireland and the more northern parts of England. It could be argued that given the low suitability for $M$. gigas settlement in the cooler northern areas, authorisation of aquaculture sites would pose little risk. However, from a pathway perspective, prohibiting the authorisation of aquaculture sites in these locations would be more effective since introduction and spread from outside this area by the unaided pathway is unlikely.

Outputs from this study reflect one spawning season only. Also, and perhaps more crucial, this study does not consider anthropogenic vectors, such as hull fouling or ballast water exchange associated with shipping and boating, with associated activity likely to result in different patterns of risk (see Tidbury et al. 2016). For example, the presence of $M$. gigas within ports and harbours (e.g. in Southampton) that are some distance from aquaculture sites, suggests that pathways other than the unaided pathway play a role in $M$. gigas dispersal (Herbert et al. 2012; Smith et al. 2015).
Shipping (ballast water, hull fouling) pathways in particular have been highlighted as a potential route of unintentional $M$. gigas introduction. Consideration of the results from the present study in combination with relevant anthropogenic vector activity will be important to inform management. Effective control of established populations is difficult, with no successful population control approach known (Herbert et al. 2016) and spread from existing UK populations is further likely to limit the success of species controls implemented.

\section{Modelling considerations}

The accuracy of particle tracking model outputs and risk estimates in the present study is dependent on robust $M$. gigas distribution and abundance data, which are lacking at present (Herbert et al. 2012). Systematic monitoring for $M$. gigas around the UK to determine current distribution will be valuable. Outputs from this study are also impacted by a limited understanding of larval development and associated swimming behaviours, required for parameterisation (North et al. 2008; Robins et al. 2017). In the present study, $M$. gigas was assumed to exhibit upward migration during the rising tide and downward migration during the falling tide in line with observations for other bivalve species (Newell et al. 2005). A recent study (James et al. 2019) used observed vertical distributions of another bivalve species (Mytilus spp.) to infer the vertical swimming behaviour and concluded that an asymmetrical tidally driven migration where larvae swim up at the start of flood but start swimming downward at mid-flood was most appropriate. However, behaviour during ebb and low tide is not clear (James et al. 2019). The tidal behaviour used in the present study maximises dispersal and is therefore in line with the precautionary or worst-case scenario approach often used in NIS studies.

In this study larval settlement and therefore establishment risk was considered according to environmental suitability (with respect to temperature, salinity, ocean depth and substrate type). However, it is likely that factors not considered in the present study will influence establishment success. For example, nutrients, such as chlorophyll $a$ and other resources are required for growth of $M$. gigas, with limitations on carrying capacity of wild populations in close proximity to aquaculture sites documented (Dame and 
Prins 1997; Leguerrier et al. 2004; Forrest et al. 2009), potentially affecting population establishment and persistence (Teixeira Alves et al. in prep). Further, hydrodynamic conditions, such as from turbulence and waves, are known to influence larval settlement (Fuchs et al. 2015). Hydrodynamic connectivity is also known to be an important process in the recruitment of marine invertebrates, playing a key role in the biological and community spatial structure of coastal lagoons (Lagarde et al. 2019).

There is currently some uncertainty regarding the precise environmental conditions under which broadcast spawners such as M. gigas spawn in the field, with high interannual and geographic variation in spawning period reported (Bernard et al. 2016). For example, $M$. gigas spawning has been reported to occur as early as June-July (Lango-Reynoso et al. 2006) and as late as October in northern France (Pouvreau et al. 2016). Whilst altering the spawning period will affect larval dispersal due to differing tidal and wind conditions, previous studies suggest that effects on dispersal distance are unlikely to be significant (Robins et al. 2017). Further, for the purpose of the present study, all spawning sites were assumed to be reproductively active. Due to debate regarding whether M. gigas is currently able to develop and spawn at their northern boundary $\left(60^{\circ} \mathrm{N}\right)$ (Thomas et al. 2016; Robins et al. 2017), the approach was precautionary, in line with NIS management, with climate change projections of warming seas likely resulting in favourable temperature conditions for spawning and settlement, and increased dispersal in the future, regardless (Diederich et al. 2005; Thomas et al. 2016; Rinde et al. 2017). Future changes to the marine environment, such as changes to ocean circulation patterns and sea temperature rises associated with climate change, may influence marine NIS introduction and spread risk. Here, the particle tracking model was run based on historic hydrodynamic conditions. While basing analyses on the maximum score across the three years is a worst-case scenario, it does not account for potential future projections under potential climate change scenarios. Extension of the study to account for changing conditions associated with climate change will be a valuable next step. Further, aquaculture practices, such as triploidy, practiced in France, (Normand et al. 2008), are likely to reduce the potential for dispersal from aquaculture sites, indicating that results from this study may overestimate dispersal associated with aquaculture sites.

In addition, global socioeconomic changes, such as increased transport networks, changes in global trade routes, and increased artificial offshore substrate, may impact the importance of recognised pathways and vectors, and perhaps lead to the emergence of novel pathways and vectors. One example of this, is the recent recognition that marine litter is a NIS introduction vector, with hydrodynamic currents facilitating the short- and long-range dispersal of NIS on this vector (Rech et al. 2016). Fouling species, including $M$. gigas, have been reported rafting on anthropogenic litter pollution (Rech et al. 2018). Policy decisions should be made with full consideration of how future changes in the prevalence of existing and emerging pathways and vectors may influence the effectiveness of management actions in mitigating the risk of introduction and secondary spread.

While this study focuses on M. gigas, the unaided pathway is likely to be an important contributor to propagule pressure in ecologically similar species, with characteristic life-history traits of successful marine invaders often including high levels of fecundity, large numbers of propagules and long larval duration (from a few days to several months) (Cardeccia et al. 2018). In the UK, other NIS with a long pelagic phase that may exhibit similar patterns of spread include Amphibalanus amphitrite (4-18 days; Anil et al. 1995) and Crepidula fornicata (14-21 days; Shanks 2009).

\section{Conclusions}

Modelling tools represent a powerful approach for furthering understanding and enhancing predictions of invasion risk. While for obvious reasons management of NIS is focussed on human mediated pathways, costeffective management requires broad understanding and consideration of all relevant vectors and pathways, and transboundary management to ensure coordinated, effective mitigation. Further, understanding risk associated with the unaided pathway is likely to increase the probability of early detection, particularly when integrated with highly sensitive molecular detection techniques such as eDNA, and facilitate containment. 
Acknowledgements This work was supported by the Department for Environment Food and Rural Affairs (Defra) contract C7699 (2019-2020). The authors would like to thank Francis Kerchof, Cécile Massé, and Arjan Gittenberger for their guidance with defining particle tracking scenarios.

Authors' contributions TS, HT, LF, PS and LEW conceived the ideas and designed the methodology; TS generated particle tracking data; $\mathrm{RH}$ and $\mathrm{AK}$ conducted the environmental suitability analysis; HT conducted the risk mapping. LEW and HT parameterised the scenarios and led the writing of the manuscript. PS and HT secured funding the work. All authors contributed to drafts and gave final approval for publication.

Funding This work was funded by Defra under contract C7699 FY19-20.

Availability of data and material Request from authors.

Code availability (software application or custom code) GETM Model: https://sourceforge.net/projects/getm/, GITM: Request from authors, GITM postprocessing tools: https://github.com/CefasRepRes/gitm-utils.

\section{Compliance with ethical standards}

Conflict of interest The authors declare no competing financial interests.

\section{Ethics approval N/A.}

Consent to participate The authors declare they consent to participate.

Consent for publication The authors declare they consent for publication.

Open Access This article is licensed under a Creative Commons Attribution 4.0 International License, which permits use, sharing, adaptation, distribution and reproduction in any medium or format, as long as you give appropriate credit to the original author(s) and the source, provide a link to the Creative Commons licence, and indicate if changes were made. The images or other third party material in this article are included in the article's Creative Commons licence, unless indicated otherwise in a credit line to the material. If material is not included in the article's Creative Commons licence and your intended use is not permitted by statutory regulation or exceeds the permitted use, you will need to obtain permission directly from the copyright holder. To view a copy of this licence, visit http://creativecommons.org/licenses/by/4.0/.

\section{References}

Adams TP, Miller RG, Aleynik D, Burrows MT (2014) Offshore marine renewable energy devices as stepping stones across biogeographical boundaries. J Appl Ecol 51:330-338. https://doi.org/10.1111/1365-2664.12207

Anil AC, Chiba K, Okanoto K, Kurokura H (1995) Influence of temperature and salinity on larval development of Balanus amphitrite: implications in fouling ecology. Mar Ecol Prog 118:159-166. https://doi.org/10.3354/meps118159

Arakawa KY (1990) Commercially important species of oysters in the world. Mar Behav Physiol 17:1-13

Bernard I, Massabuau JC, Ciret P, Sow M et al (2016) In situ spawning in a marine broadcast spawner, the Pacific oyster Crassostrea gigas: timing and environmental triggers. Limnol Oceanogr 61:635-647. https://doi.org/10.1002/lno. 1024

Berrisford P, Dee D, Poli P et al (2011) The ERA-Interim archive, version 2

Booy O, Mill AC, Roy HE, Hiley A et al (2017) Risk management to prioritise the eradication of new and emerging invasive non-native species. Biol Invasions 19:2401-2417. https://doi.org/10.1007/s10530-017-1451-z

Brandt G, Wehrmann A, Wirtz KW (2008) Rapid invasion of Crassostrea gigas into the German Wadden Sea dominated by larval supply. JSR 59:279-296. https://doi.org/10.1016/ j.seares.2008.03.004

Burchard H, Bolding K, Hansen C, Mattsson J (2002) A coupled model for the North Sea and the Baltic Sea with general vertical coordinates. In: EGS general assembly conference abstracts, vol 27

Cardeccia A, Marchini A, Occhipinti-Ambrogi A et al (2018) Assessing biological invasions in European seas: biological traits of the most widespread non-indigenous species. Estuar Coast Shelf Sci 201:17-28. https://doi.org/10.1016/ j.ecss.2016.02.014

Cardoso JFM, Langlet D, Loff JF et al (2007) Spatial variability in growth and reproduction of the Pacific oyster Crassostrea gigas (Thunberg 1793) along the west European coast. J Sea Res 57:303-315. https://doi.org/10.1016/j. seares.2006.11.003

Cassey P, García-Díaz P, Lockwood JL, Blackburn TM (2018) Invasion biology: searching for predictions and prevention and avoiding lost causes. In: Jeschke JM, Heger T (eds) Invasion biology: hypotheses and evidence. CABI, Boston

Castaños C, Pascual M, Camacho AP (2009) Reproductive biology of the nonnative oyster, Crassostrea gigas (Thunberg, 1793), as a key factor for its successful spread along the rocky shores of northern Patagonia, Argentina. JSR 28:837-847. https://doi.org/10.2983/035.028.0413

Convention on Biological Diversity (2014) Pathways of introduction of invasive species, their prioritization, and management. Convention on Biological Diversity, Montreal

Collet B, Boudry P, Thebault A et al (1999) Relationship between pre-and post-metamorphic growth in the Pacific oyster Crassostrea gigas (Thunberg). Aquaculture 175:215-226. https://doi.org/10.1016/S00448486(99)00042-3

Copp GH, Godard MJ, Russell IC et al (2016) A preliminary evaluation of the European non-native species in aquaculture risk assessment scheme applied to species listed on Annex IV of the EU alien species regulation. FME 23:12-20. https://doi.org/10.1111/fme.12076

Coolen JWP, Boon AR, Crooijmans R et al (2020) Marine stepping-stones: connectivity of Mytilus edulis populations 
between offshore energy installations. Mol Ecol 29:687-703. https://doi.org/10.1111/mec.15364

Coon S, Fitt W, Bonar D (1990) Competence and delay of metamorphosis in the Pacific oyster Crassostrea gigas. Mar Biol 106:379-387. https://doi.org/10.1007/ BF01344316

d'Auriac MBA, Rinde E, Norling P et al (2017) Rapid expansion of the invasive oyster Crassostrea gigas at its northern distribution limit in Europe: naturally dispersed or introduced? PLoS ONE 12. https://doi.org/10.1371/journal. pone. 0177481

Dame RF, Prins TC (1997) Bivalve carrying capacity in coastal ecosystems. Aquat Ecol 31:409-421. https://doi.org/10. 1023/A:1009997011583

Dauvin JC, Pezy JP, Baffreau A (2019) The English channel: becoming like the seas around Japan. In: Oceanography challenges to future earth. Springer, Cham, pp 105-120

De Mesel I, Kerckhof F, Norro A et al (2015) Succession and seasonal dynamics of the epifauna community on offshore wind farm foundations and their role as stepping stones for non-indigenous species. Hydrobiologia 756:37-50. https:// doi.org/10.1007/s10750-014-2157-1

Dee DP, Uppala SM, Simmons AJ et al (2011) The ERA-Interim reanalysis: configuration and performance of the data assimilation system. QJRMS 137:553-597. https://doi.org/ 10.1002/qj.828

Diederich S (2005) Invasion of Pacific oysters (Crassostrea gigas) in the Wadden Sea: competitive advantage over native mussels. Dissertation, Kiel University

Diederich S, Nehls G, Van Beusekom J, Reise K (2005) Introduced Pacific oysters (Crassostrea gigas) in the northern Wadden Sea: invasion accelerated by warm summers? Helgol Mar Res 59:97-106. https://doi.org/10.1007/ s10152-004-0195-1

Dutertre M, Beninger PG, Barillé L et al (2010) Rising water temperatures, reproduction and recruitment of an invasive oyster, Crassostrea gigas, on the French Atlantic coast. Mar Environ Res 69:1-9. https://doi.org/10.1016/j. marenvres.2009.07.002

Ellis T, Gardiner R, Gubbins et al (2015) Aquaculture statistics for the UK, with a focus on England and Wales 2012. Centre for Environ Fish. \& Aquac Sci. (Cefas) Weymouth

Essl F, Bacher S, Blackburn TM et al (2015) Crossing frontiers in tackling pathways of biological invasions. BioScience 65:769-782. https://doi.org/10.1093/biosci/biv082

FAO (2016) Species fact sheets: Crassostrea gigas (Thunberg, 1793). http://www.fao.org/fishery/species/3514/en. Accessed 01 Jan 2020

FAO (2019) Species fact sheets: Crassostrea gigas. FAO Fisheries and Aquaculture Department, Rome. http://www. fao.org. Accessed 01 Feb 2020

Forrest BM, Keeley NB, Hopkins GA et al (2009) Bivalve aquaculture in estuaries: review and synthesis of oyster cultivation effects. Aquaculture 298:1-15. https://doi.org/ 10.1016/j.aquaculture.2009.09.032

Fuchs HL, Gerbi GP, Hunter EJ et al (2015) Hydrodynamic sensing and behavior by oyster larvae in turbulence and waves. J Exp Biol 218:1419-1432. https://doi.org/10.1242/ jeb. 118562

Galtsoff PS (1964) The American oyster, Crassostrea virginica Gmelin, vol 64. US Government Printing Office
GB NNSS (2010) GB non-native organism risk assessment. GB non-native species secretariat. http://www. nonnativespecies.org//index.cfm?sectionid=51. Accessed 01 July 2019

GBIF (2019) Magallana gigas (Thunberg, 1973) GBIF backbone taxonomy checklist dataset. https://www.gbif.org/ species/7820753. Accessed via GBIF.org on 29 July 2019

Helm MM (2004) Hatchery culture of bivalves: a practical manual (No. 639.2 F3 v. 471). FAO

Herbert RJH, Roberts C, Humphreys J, Fletcher S (2012) The Pacific oyster (Crassostrea gigas) in the UK: economic, legal and environmental issues associated with its cultivation, wild establishment and exploitation. Report for the Shellfish Association of Great Britain

Herbert RJ, Humphreys J, Davies CJ et al (2016) Ecological impacts of non-native Pacific oysters (Crassostrea gigas) and management measures for protected areas in Europe. Biodivers Conserv 25:2835-2865. https://doi.org/10.1007/ s10531-016-1209-4

Hijmans RJ (2019) raster: geographic data analysis and modelling. R package version 2.8-19. https://CRAN.R-project. org/package=raster. Accessed 01 June 2019

Hill AE, Brown J, Fernand L et al (2008) Thermohaline circulation of shallow tidal seas. Geophys Res Lett 35:L11605. https://doi.org/10.1029/2008GL033459

Hulme PE (2015) Invasion pathways at a crossroad: policy and research challenges for managing alien species introductions. J Appl Ecol 52:1418-1424. https://doi.org/10.1111/ 1365-2664.12470

Hulme PE, Bacher S, Kenis M et al (2008) Grasping at the routes of biological invasions: a framework for integrating pathways into policy. J Appl Ecol 45:403-414. https://doi.org/ 10.1111/j.1365-2664.2007.01442.x

James MK, Polton JA, Brereton AR et al (2019) Reverse engineering field-derived vertical distribution profiles to infer larval swimming behaviors. PNAS 116:11818-11823. https://doi.org/10.1073/pnas.1900238116

Join Nature Conservation Committee (2019) Marine recorder (online). http://wwwjncc.defra.gov.uk/page-1599. Accessed 28 June 2019

Knights AM, Crowe TP, Burnell G (2006) Mechanisms of larval transport: vertical distribution of bivalve larvae varies with tidal conditions. MEPS 326:167-174. https://doi.org/10. 3354/meps326167

Kochmann J (2012) Into the wild, documenting and predicting the spread of Pacific oysters (Crassostrea gigas) in Ireland. Dissertation, University College Dublin

Kochmann J, O’Beirn F, Yearsley J, Crowe TP (2013) Environmental factors associated with invasion: modelling occurrence data from a coordinated sampling programme for Pacific oysters. Biol Invasions 15:2265-2279. https:// doi.org/10.1007/s10530-013-0452-9

Lagarde F, Fiandrino A, Ubertini M, d Orbcastel et al (2019) Duality of trophic supply and hydrodynamic connectivity drives spatial patterns of Pacific oyster recruitment. Mar Ecol Prog Ser 632: 81-100. https://doi.org/10.3354/ meps13151

Lallias D, Boudry P, Batista FM et al (2015) Invasion genetics of the Pacific oyster Crassostrea gigas in the British Isles inferred from microsatellite and mitochondrial markers. 
Biol Invasions 17:2581-2595. https://doi.org/10.1007/ s10530-015-0896-1

Lango-Reynoso F, Chavez-Villaba J, Le Pennec M (2006) Reproductive patterns of the Pacific oyster Crassostrea gigas in France. Invertebr Reprod Dev 49:41-50. https:// doi.org/10.1080/07924259.2006.9652192

Le Provost C, Lyard F, Molines JM et al (1998) A hydrodynamic ocean tide model improved by assimilating a satellite altimeter-derived data set. J Geophys Res Oceans 103:5513-5529. https://doi.org/10.1029/97JC01733

Leguerrier D, Niquil N, Petiau A, Bodoy A (2004) Modeling the impact of oyster culture on a mudflat food web in Marennes-Oléron Bay (France). Mar Ecol Prog Ser 273:147-162. https://doi.org/10.3354/meps 273147

Mann R (1979) Some biochemical and physiological aspects of growth and gametogenesis in Crassostrea gigas and Ostrea edulis grown at sustained elevated temperatures. J Mar Biol Assoc UK 59:95-110. https://doi.org/10.1017/ S0025315400046208

Mann R, Burreson EM, Baker PK (1991) The decline of the Virginia Oyster fishery in Chesapeake Bay considerations for introduction of a non-endemic species, Crassostrea gigas (Thunberg, 1793). J Shellfish Res 10:379

Natural England (2009) Pacific oyster survey of the North East Kent European marine sites. Natural England commissioned report NECR016

Newell RI, Fisher TR, Holyoke RR, Cornwell JC (2005) Influence of eastern oysters on nitrogen and phosphorus regeneration in Chesapeake Bay, USA. In: The comparative roles of suspension-feeders in ecosystems. Springer, Dordrecht, pp 93-120

Nicolle A, Moitié R, Ogor J et al (2017) Modelling larval dispersal of Pecten maximus in the English Channel: a tool for the spatial management of the stocks. IJMS 74:1812-1825. https://doi.org/10.1093/icesjms/fsw207

Normand J, Le Pennec M, Boudry P (2008) Comparative histological study of gametogenesis in diploid and triploid Pacific oysters (Crassostrea gigas) reared in an estuarine farming site in France during the 2003 heatwave. Aquaculture 282:124-129. https://doi.org/10.1016/j. aquaculture.2008.06.026

North EW, Schlag Z, Hood RR et al (2008) Vertical swimming behavior influences the dispersal of simulated oyster larvae in a coupled particle-tracking and hydrodynamic model of Chesapeake Bay. Mar Ecol Prog Ser 359:99-115. https:// doi.org/10.3354/meps07317

Otto L, Zimmerman JT, Furnes GK et al (1990) Review of the physical oceanography of the North Sea. Neth J Sea Res 26:161-238. https://doi.org/10.1016/00777579(90)90091-T

Pingree RD (1980) Physical oceanography of the Celtic sea and English channel. In: Elsevier oceanography series, vol 24. Elsevier, pp 415-465

Pouvreau S, Maurer D, Auby I et al (2016) Velyger database: the oyster larvae monitoring French project. http://wwz. ifremer.fr/velyger/Acces-aux-Donnees/Rade-de-Brest/ Maturation. Accessed 17 May 2019

R Core Team (2019) RStudio: integrated development for R. RStudio, Inc., Boston http://www.rstudio.com/. Accessed Oct 2019
Rech S, Borrell Y, García-Vazquez E (2016) Marine litter as a vector for non-native species: what we need to know. Mar Pollut Bull 113:40-43. https://doi.org/10.1016/j. marpolbul.2016.08.032

Rech S, Borrell Y, García-Vazquez E (2018) Anthropogenic marine litter composition in coastal areas may be a predictor of potentially invasive rafting fauna. PLoS ONE 13:e0191859. https://doi.org/10.1371/journal.pone. 0191859

Rico-Villa B, Pouvreau S, Robert R (2009) Influence of food density and temperature on ingestion, growth and settlement of Pacific oyster larvae, Crassostrea gigas. Aquaculture 287:395-401. https://doi.org/10.1016/j. aquaculture.2008.10.054

Rinde E, Tjomsland T, Hjermann D et al (2017) Increased spreading potential of the invasive Pacific oyster (Crassostrea gigas) at its northern distribution limit in Europe due to warmer climate. Mar Freshw Res 68:252-262. https://doi.org/10.1071/MF15071

Robins PE, Tita A, King JW, Jenkins SR (2017) Predicting the dispersal of wild Pacific oysters Crassostrea gigas (Thunberg, 1793) from an existing frontier population: a numerical study. Aquat Invasions 12:117-131. https://doi. org/10.3391/ai.2017.12.2.01

Ruesink JL, Lenihan HS, Trimble AC et al (2005) Introduction of non-native oysters: ecosystem effects and restoration implications. Ann Rev Ecol Evol Syst 36:643-689. https:// doi.org/10.1146/annurev.ecolsys.36.102003.152638

Ruiz C, Abad M, Sedano F et al (1992) Influence of seasonal environmental changes on the gamete production and biochemical composition of Crassostrea gigas (Thunberg) in suspended culture in El Grove. Galicia Spain JEMBE 155:249-262. https://doi.org/10.1016/00220981(92)90066-J

Rumrill SS (1990) Natural mortality of marine invertebrate larvae. Ophelia 32:163-198. https://doi.org/10.1080/ 00785236.1990.10422030

Salomon JC, Breton M (1993) An atlas of long-term currents in the channel. Oceanol Acta 16:439-448

Seafish (2019) 'Pacific oyster cultivation', aquaculture methods leaflet. http://www.seafish.org.uk. Accessed 06 June 2019

Shanks AL (2009) Pelagic larval duration and dispersal distance revisited. Biol Bull 216:373-385. https://doi.org/10.2307/ 25548167

Smaal AC, Wijsman JWM, Poelman M (2006) Proliferation of the Pacific oyster Crassostrea gigas in Dutch coastal waters and its consequences for human use. In: ICES annual science conference 2006, theme session G: human health risks and marine environmental quality, Maastricht

Smith IP, Guy C, Donnan D (2015) Pacific oysters, Crassostrea gigas, established in Scotland. Aquat Conserv 25:733-742. https://doi.org/10.1002/aqc. 2483

The Crown Estate (2018) Offshore wind operational report. https://www.thecrownestate.co.uk/media/2950/offshorewind-operational-report-2018.pdf. Accessed 26 June 2019

Thomas Y, Pouvreau S, Alunno-Bruscia M et al (2016) Global change and climate-driven invasion of the Pacific oyster (Crassostrea gigas) along European coasts: a bioenergetics modelling approach. J Biogeogr 43:568-579. https://doi. org/10.1111/jbi.12665 
Tidbury HJ, Taylor NG, Copp GH et al (2016) Predicting and mapping the risk of introduction of marine non-indigenous species into Great Britain and Ireland. Biol Invasions 18:3277-3292. https://doi.org/10.1007/s10530-016-1219$\mathrm{x}$

Tidbury H, Taylor NG, van der Molen J et al (2020) Social network analysis as a tool for marine spatial planning: impacts of decommissioning on connectivity in the North Sea. J Appl Ecol 57:566-577. https://doi.org/10.1111/ 1365-2664.13551

Troost K (2010) Causes and effects of a highly successful marine invasion: case-study of the introduced Pacific oyster Crassostrea gigas in continental NW European estuaries. J Sea Res 64:145-165. https://doi.org/10.1016/j. seares.2010.02.004

Troost K, Veldhuizen R, Stamhuis EJ, Wolff WJ (2008) Can bivalve veligers escape feeding currents of adult bivalves? JEMBE 358:185-196. https://doi.org/10.1016/j.jembe. 2008.02.009

Van Der Molen J, Van Beek J, Augustine S et al (2015) Modelling survival and connectivity of Mnemiopsis leidyi in the south-western North Sea and Scheldt estuaries. Ocean Sci 11:405-424. https://doi.org/10.5194/os-11-405-2015

Van der Molen J, Ruardij P, Greenwood N (2016) Potential environmental impact of tidal energy extraction in the Pentland Firth at large spatial scales: results of a biogeochemical model. Biogeosciences 13:2593-2609. https://doi.org/10.5194/bg-13-2593-2016

Visser AW (1997) Using random walk models to simulate the vertical distribution of particles in a turbulent water column. MEPS 158:275-281. https://doi.org/10.3354/ meps 158275

Wehrmann A, Herlyn M, Bungenstock F, Hertweck G, Millat G (2000) The distribution gap is closed-first record of naturally settled Pacific oysters Crassostrea gigas in the East Frisian Wadden Sea. Senckenberg Marit 30:153-160

Williams SL, Davidson IC, Pasari JR et al (2013) Managing multiple vectors for marine invasions in an increasingly connected world. Bioscience 63:952-966. https://doi.org/ 10.1525/bio.2013.63.12.8

Wrange AL, Valero J, Harkestad LS et al (2010) Massive settlements of the Pacific oyster, Crassostrea gigas, in Scandinavia. Biol Invasions 15:1145-1152. https://doi.org/ 10.1007/s10530-009-9535-Z

Zenni RD (2014) Analysis of introduction history of invasive plants in Brazil reveals patterns of association between biogeographical origin and reason for introduction. Austral Ecol 39:401-407. https://doi.org/10.1111/aec.12097

Publisher's note Springer Nature remains neutral with regard to jurisdictional claims in published maps and institutional affiliations. 